obtained through the great omentum. My colleague, Mr. Furner, in a paper on complications arising in this condition, pointed out that subphrenic abscess often followed a focus of infection in the lesser peritoneal cavity. He alluded to my suggestion of opening this cavity as a matter of routine and urged that the liability to subphrenic abscess was an additional argument in favour of adopting this rule. It should be done at the end of the operation, for if flushing has been the mode chosen for cleansing the abdominal cavity portions of septic matter may have been carried through the foramen of Winslow and so have fouled the lesser cavity which was perhaps fairly clean. I hold that flushing with hot saline solution aided by gentle but careful exploration with the fingers of all peritoneal recesses forms the best method of cleansing. Before flushing is begun I insert a glass tube into the pelvis through a separate opening above the pubes. I then cleanse the lower two-thirds of the abdominal cavity and remove portions of food, shreds of lymph, \&c., which will have run down largely into the pelvis. After a while the fluid will run out clear as it went in. Turning then to the upper part of the cavity we shall open in succession various recesses with fresh collections, all of which will be swept down and out through the glass tube. By doing this systematically we shall escape much risk of leaving some part uncleansed. When, finally, no fresh clouding of the saline solution is seen we shall know that the peritoneum is clean. I know well that there are cases in which nothing short of sponging will remove adherent lymph, but, as a rule, I believe that the washing and gentle use of soft finger-tips will do as well.

Brighton.

\section{EXFOLIATION OF THE COCHLEA.}

By F. FAulder White, F.R.C.S. ENG.

HOYORARY SURGEON TO THE COVEXTRY AND WARWICKSHIRE HOSPITAL.

THE patient was a woman, aged twenty-eight years. She had suffered from a discharge from the right ear from childhood. In September, 1897, she had a severe illness, her account of which is as follows: "It began with severe pain in the ear and right side of the head. I had constant vomiting for twenty-four hours. I became delirious and did not know where I was for several days. The doctors applied ice to the head and poulticed the ear. I was in bed for six weeks.' She gradually got better but has been in poor health ever since. The discharge continued to be profuse and was very offensive. She says that her medical attendant told her that it would be very dangerous to check the discharge. She came under my care in October. I found the middle ear full of an offensive discharge and she was quite deaf on the right side. Having admitted her into the hospital I ordered frequent syringing with a hot solution of silico-fluoride. The patient rapidly improved but there were two or three polypi which required removal, and while extracting these my forceps brought away a small piece of bone which was loose in the middle ear. This proved to be the modiolus of the cochlea with part of the osseus spiral lamina. The patient made a rapid and perfect recovery. The ear is now dry and sweet, the inner wall presenting a regular surface, and there is nothing in its appearance to reveal the somewhat unusual deficiency.

Such a case as this shows what nature can sometimes effect without operative interference and every month furnishes me with fresh proof of the reparative powers of the tissues in the middle ear and the adjoining cavities. The vitality of the tissues is lowered by septic organisms, but even after half a lifetime of neglected otorrhoea the middle ear may be restored to health by proper treatment. Yet half the patients who come to me have been under treatment elsewhere without relief or have been professionally advised that it was dangerous to meddle with the ear. Even in works on otology one fails to find any adequate protest against the everyday neglect of this disease. Some aural surgeons, indeed, write as if nothing could be more dangerous, but the hope held out is through operative interference. In uncomplicated cases this is, to say the least, unnecessary.

Coventry d edthror

\section{HOSPITAL PRACTICE, BRITISH AND FOREIGN.}

Nulla autem est alia pro certo noscendi via, nisi quamplurimas et morborum et dissectionum historias, tum aliorum tum proprias collectas habere, et inter se comparare.-MoRGAGNI De Sed. et Caus. Morb., lib. iv. Proœmium.

\section{UNIVERSITY COLLEGE HOSPITAL.}

A CASE OF GUMMATOUS ULCERATION OF THE SCALP BECOMING EPITHELIOMATOUS; TREATMENT BY SCRAPING.

(Under the care of Mr. A. E. J. BARKER).

THE chief interest in this case is connected with the occurrence of an epitheliomatous ulcer on the scalp in as patient thirty years of age. The history of the case and the characters of the ulcer when first seen were definitely in favour of a gummatous origin, but the failure of the antisyphilitic treatment and the histological examination of a portion of the margin of the ulcer proved fairly conclusively that it was epitheliomatous in nature. The phenomenon of a gummatous ulcer developing into a squamous carcinoma is not rarely to be seen in the tongue and occasionally on the lower limbs, but so far as we are aware it has not hitherto been described as occurring on the scalp in a patient of this age.

A woman, aged thirty years, was admitted into University College Hospital on Dec. 2nd, 1896. Four years previously she had had a somewhat prominent pimple on the vertex of her head; this was accidentally pricked with a hat pin and a scab formed; when the scab came off a small ulcer was left. A little later a blind fell on to it and made it bleed. It had been operated on on two occasions at another hospital and she had been treated medicinally, but no real improvement had resulted and the ulcerated area had steadily grown larger. There was nothing in the family history of importance except that an aunt was said to have died from cancer. On admission the patient appeared to be in fairly good health and nothing abnormal was found in any thoracic or abdominal organ. On the vertex of the scalp, rather to the right of the middle line, was a large irregular ulcerated surface measuring about $2 \mathrm{in}$. in diameter. The margin of the ulcer was crenated and the edge was fairly sharply cut except on the right where it was raised and slightly everted. The depth of the ulcer varied, but towards the right side it was nearly $\frac{3}{4} \mathrm{in}$. deep. The floor was covered with slough and discharge and at one part there was an evident pulsation. The ulcer was thoughi to be probably gummatous, though the edge in parts looked epitheliomatous. On admission 5 grains of iodide of potassium were prescribed with tonics and cod-liver oil, and the sore was dressed with sal alembroth gauze. The amount of iodide of potassium was doubled on the 7th and the ulcer was dressed with lotio rubra. The patient was much troubled with constipation which, however, soon yielded to treatment. On the 19th the iodide of potassium was increased to 30 grains three times a day. On Jan. 1st lotio nigra was used to the ulcer, but it appeared to cause a good deal of sloughing, so it was discontinued and lotio rubra was used once more on the 3rd. The ulcer did not make any definite progress, neither did it get any worse. On the 5th the patient complained of severe headache, and caffeine citrate and phenacetin were ordered at night to relieve it. On the 7th the iodide of potassium mixture was ordered to be given in the morning only, and mercurial ointment was ordered to be rubbed into the thighs once a day. The ulcer began to clear up and some of the sloughs separated, and lead lotion was substituted for the lotio rubra, but by Feb. 1st it was evident that very little real improvement had taken place and some fresh small outlying ulcers were noticed. A week later a nitrate of silver lotion (four grains to the ounce) was used. On the 20th, as the ulcer showed no signs of healing, nitrous oxide gas was administered and Mr. Barker removed a small piece of the thickened edge of the ulcer for diagnostic purposes. When this piece was examined microscopically it 